\title{
Effect of concentrate supplementation on milk production of spring calving dairy cows with restricted herbage allowance and subsequent carryover effects
}

\author{
C Wims ${ }^{1,2}$, T Boland $^{1}$, L Delaby $^{3}$, M O'Donovan $^{1}$
}

${ }^{1}$ Moorepark Dairy Production Research Centre, Fermoy, Co Cork, Ireland

${ }^{2}$ School of Agriculture, Food Science and Veterinary Medicine, NUI Dublin, Belfield Dublin 4, Ireland

${ }^{3}$ INRA, UMR Production du Lait, 35590 St Gilles, France

Email:cathal.wims@teagasc.ie

Introduction Irish dairy production systems are mainly pasture-based spring calving herds. Replacing grass silage with grazed grass in the diets of spring calving cows in early lactation will reduce production costs on Irish dairy farms. Dillon et al. (2005) has shown that 10\% increase in the proportion of grazed grass in the diet will reduce the cost of milk produced $2.5 \mathrm{c} /$ litre. Also replacing grass silage with grazed grass in the diet of spring calving dairy cow in early lactation has milk production performance benefits, including increasing milk protein content (Kennedy et al., 2005). However due to the seasonal pattern of grass growth in Ireland, grass supply in early spring is generally not sufficient to meet the cow's demand. As a result, it is sometimes necessary to restrict access to grass and supplement with concentrate in early lactation. The objective of this experiment was to establish the effect of concentrate supplementation on milk production of spring calving dairy cows in early lactation with restricted daily herbage allowance.

Material and methods Fifty-seven (24 primiparous and 33 multiparous) spring calving Holstein Friesian dairy cows (mean calving date 3 February; s.d. 13.1 days) were balanced on lactation number (2.3; s.d. 1.6), milk yield (22.2kg; s.d. 4.99), bodyweight (513kg; s.d. 62.99) and body condition score (3.19; s.d. 0.53) in a randomised block design. Animals were randomly assigned to a 3 treatment $(\mathrm{n}=19)$ grazing study -3 concentrate (conc.) levels for a 44 day period ( $23 \mathrm{Feb}$. until 7 April). The treatments were: L1 - $1 \mathrm{~kg}$ fresh weight (FW) conc./cow; L3.5 - $3.5 \mathrm{~kg} \mathrm{FW} \mathrm{conc./cow} \mathrm{and} \mathrm{L6} \mathrm{-} 6 \mathrm{~kg}$ FW conc./cow. All cows grazed together for the duration of the experiment. Daily herbage allowance was governed using a post grazing height of 3-3.5 cm. Fresh herbage was allocated daily. Herbage mass and sward density was measured twice weekly by cutting four strips per grazing area. Pre and post-grazing sward heights were measured daily. Milk yield was recorded daily, milk composition and bodyweight (BW) were measured weekly. Body condition score (BCS) was also measured. Animal variables were analysed using covariate analysis in SAS. Parity, treatment, parity * treatment interaction, days in milk and the pre experimental covariates were included in the model. Linear and quadratic effects on milk yield, milk fat, protein and lactose content, milk solids yield, solids corrected yield (SCM), BW change and BCS change were also tested.

Results Animal performance results are shown in Table 1. Mean pre-grazing sward height was $7.7 \mathrm{~cm}$ (s.e. 0.15$)$, while post grazing sward height was $3.2 \mathrm{~cm}$ (s.e 0.06.). Mean pre-grazing herbage mass was $1120 \mathrm{~kg} \mathrm{DM} / \mathrm{ha}$. Mean daily herbage allowance (DHA) was $12 \mathrm{~kg} \mathrm{DM} / \mathrm{cow} /$ day. Increasing conc. allowance from L1 to L3.5 significantly increased $(\mathrm{P}<0.005)$ milk yield, solids corrected milk yield, milk protein yield and milk lactose yield. Increasing conc. allowance from L3.5 to L6 had no significant effect on milk production performance. Treatment had no effect on BW or BCS change with a large BW and BCS loss recorded across all treatments. Milk response to concentrate was $0.72 \mathrm{~kg}$ milk $/ \mathrm{kg}$ conc. increasing conc. from L1 to L3.5 with no response in milk production increasing conc. from L3.5 to L6. In terms of carryover effects; cows offered the highest level of concentrate, L6, continued to yield the highest four weeks after the trial ceased. However all groups equalised for milk yield eight and twelve weeks after trial completion.

Table1 Effect of concentrate supplementation on dairy cow performance in early lactation

\begin{tabular}{lllllll}
\hline \hline & \multicolumn{7}{l}{$\mathrm{kg}$ conc FW*/cow/day } & & \\
\cline { 2 - 7 } & 1 & 3.5 & 6 & SED & Sig. & Linear \\
\hline Milk yield (kg/day) & 23.3 & 25.1 & 25.2 & 0.69 & 0.0156 & 0.0097 \\
Milk fat content $(\mathrm{g} / \mathrm{kg})$ & 4.17 & 4.24 & 4.09 & 1.12 & 0.4388 & 0.4750 \\
Milk protein content $(\mathrm{g} / \mathrm{kg})$ & 3.16 & 3.14 & 3.20 & 0.52 & 0.5821 & 0.4888 \\
Milk lactose content $(\mathrm{g} / \mathrm{kg})$ & 4.80 & 4.79 & 4.79 & 0.23 & 0.8654 & 0.6454 \\
Milk solids yield (g/day) & 1710 & 1832 & 1839 & 62.36 & 0.0804 & 0.0434 \\
SCM yield (kg/day) & 22.4 & 23.0 & 23.0 & 0.79 & 0.0737 & 0.0460 \\
Bodyweight change $(\mathrm{kg})$ & -49.3 & -53.0 & -44.3 & 12.11 & 0.7868 & 0.6875 \\
BCS change & -0.66 & -0.68 & -0.63 & 0.06 & 0.7927 & 0.6835 \\
\hline \hline
\end{tabular}

*FW $=$ Fresh Weight

Conclusion These results suggest that where herbage allowance is restricted in early lactation, there is no response to feeding high levels of concentrate and that a moderate level of concentrate feeding will stimulate a milk production response. Cows across all treatments lost a substantial amount of body condition as indicated by the BCS change. This indicates that concentrate supplementation

will not prevent mobilisation of body reserves where herbage allowance is restricted in early lactation.

\section{References}

Dillon, P., Roche, J.R., Shallo, L. and Horan, B. 2005. International Grassland Congress, Cork, Ireland. 20, 131-147.

Kennedy, E., O’Donovan, M., Murphy, J.P., and O’Mara, F. 2005. Grass and Forage Science. 60, 310-318. 